It was the first international European body to become involved in guidelines for recombinant DNA research, and has a Standing Advisory Committee on Recombinant DNA chaired by Professor Charles Weissmann. This was set up in January 1976 and held its first meeting in London the following month to discuss whether it was worth elaborating guidelines, other than those available, for Europe as a whole.

At its second meeting, in London last September, the committee compared the NIH and Williams guidelines. It suggested the establishment of national advisory groups to specify containment measures for each experiment on the basis of a detailed protocol submitted to it. The committee specifically recommended against the idea of using some combination of the procedures from the two sets of guidelines. And it advised that experiments forbidden under the NIH guidelines not be carried out.

The European Science Foundation (ESF). Established in November 1974, the ESF is made up of 45 national research councils and academies from 18 European countries and aims to create a close-knit community of science and research in Europe. Sweden quickly suggested to the founding committee that it should consider the whole question of genetic manipulation, including its social, legal and ethical aspects. With the EMBO committee able only to provide advice on request, and then only about scientific and technical aspects, the ESF decided in October 1975 to broaden a preparatory working party into an ad hoc committee on Recombinant DNA which could propose through ESF members whether and what action should be taken at European level.

The committee met three times in 1976 under the chairmanship of Professor Povl Riis of Denmark; members included molecular biologists, physicians and lawyers. Their brief was broad, and they concluded that the recommendations and code of practice of the Williams report should be adopted as the guidelines for recombinant DNA research in Europe. They also recommended that national registries of research should be established and that laboratories should be legally obliged to declare their work to it; laboratories would adhere to agreed guidelines voluntarily, however, and supervision and monitoring would be a national responsibility. National variations, it suggested, should be minimised.

The ESF has now created a new committee made up of representatives of the geemags of its members with the aim of proposing guidelines for Europe. This European Committee on Recombinant DNA will meet for the first time in Strasbourg on 15 March. It will note differences in the practices of various countries and consider prescribing measures for the future.

The European Commission. The European Commission, which has a dual role in the EEC of both initiating and implementing Community legislation, finally jumped into the fray in January. Spotting the opportunity provided by a potential need for Community-wide legislation and harmonisation, Directorate General XII (Research, Science and Education), headed by Dr Gunter Schuster, called geemag heads to Brussels on 21 January for "informal consultations". This offended some sensibilities, not least because Dr Schuster was seeing members of the new ESF committee on which he is himself the EEC's representative.

The Commission is apparently contemplating a directive, the device by which it can request member states to modify and harmonise their legislation. In the case of recombinant DNA research this might involve asking the Nine to ensure that they take the same precautions, but not interfering with the operations of individual gcemags. At the January meeting there was no stern objection to the idea, provided a directive was not too specific or detailed.

The worry is not chiefly about Commission interference, although its record in science is less adequate that it might be. Most people recognise that it possesses the authority both to hasten the necessary harmonisation and to incorporate research done in the private sector a common framework. The worry for the moment is related more to the style and timing of the Commission's involvement, which could be self-defeating if it breeds resentment among researchers.

The outcome of the January meeting was presented last week at a meeting in Brussels of the Medical Research Committee, a sub-committee of CREST, the Commission's Scientific and Technical Research Committee. According to the office of the director of the biology programme, the meeting reached no firm conclusions and is due to meet again only in June. That may mean that EEC invlovement will remain peripheral for a while yet. If so, the immediate burden of recommending a path for recombinant DNA research in Europe now lies with the ESF.

\title{
From Carter via Ford
}

Colin Norman reports from Washington on President Carter's proposed budget changes

AFTER three weeks of frantically sifting through the massive set of budget proposals which President Ford left behind, President Carter last week sent Congress a raft of major and minor amendments. Designed to implement some of Carter's more prominent election promises and political priorities, the proposed budget revisions would undo some of the Ford Administration's parsimony toward health, welfare and housing programmes and add about $\$ 19,400$ million to previous estimates of government spending in the 1978 fiscal year (which begins on 1 October, 1977).

As far as science and technology are concerned, the only areas which figured prominently in campaign rhetoric were energy and military research and development, and consequently they are the only areas greatly affected by Carter's proposed budget revisions. Outside those two fields, Carter has proposed a small addition to Ford's budget for NASA for studies of possible follow-up missions to the Mars Viking Lander project, and a $\$ 5$ million increase in the budget of National Institutes of Health (NIH) for research on childhood diseases. Otherwise, the relatively large budget increases for basic research, earthquake prediction and agricultura, research proposed by President Ford have been left untouched.

The proposed revisions to the budget for energy research and development are another matter. Acting on the advice of James Schlesinger, his energy adviser, Carter has scaled down Ford's budget proposals for three longterm energy programmes-the breeder reactor, development of large solar power plants and thermonuclear fusion -and redirected some of the funds towards efforts likely to produce shortterm results. The proposals signal a major shift in priorities and indicate that the new Administration is prepared to play a more aggressive role than its predecessor in pushing new technologies, such as solar heaters and electrically powered automobiles. into the market-place. The budget pro- 


\section{Press report}

$\mathrm{Ir}$ is now virtually certain that President Carter will name Frank Press, a distinguished geophy'sicist from the Massachusetts Instifute of lechnology, as his science adviser and head of the White House Office of Science and Technology Policy (OSTP). Though no official announcement had been made by the end of last week, Press was already at work in the White House, helping to select candidates for other top science posts in the federal government and attending meetings of Carter's senior advisers. Administration sources indicated that a formal announcement was imminent.

The appointment of Press, which was first rumoured a couple of weeks ago, is something of a surprise. Although he is no stranger to the Washington science policy network, he is not generally regarded as part of the inner circle of the scientific establishment. It was, in fact, widely expected that the job would go to Lewis Branscomb, head of research at International Business Machines (IBM), who coordinated a science policy task force for Carter during the campaign. It has been suggested, however, that Branscomb was ruled out hecause several people with IBM connections had already been appointed to top posts in the Carter Administration, a fact which has attracted some criticism.

Press was recommended to Carter by a number of prominent scientists, particularly Defense Secretary Harold
Brown and Jerome Wiesner, President of MIT, and his appointment has generally been greeted with warm approval in the scientific community. An outstanding scientist, he was elected a member of the National Academy of Sciences at the age of 33 . He was Professor of Geophysics at Caltech from 1955 to 1965 and Director of the Seismological Laboratory for much of that time. Since 196.5 he has been Chairman of the Department of Earth and Planetary Sciences at MIT.

Among his credentials for the science adviser post is his wide experience in the science and politics of test ban negotiations. He has long been interested in the problem of identifying the seismic waves from underground nuclear explosions and discriminating them from signals from earthquakes. He was a United States delegate to the test ban conference in Geneva in 1960-62, which paved the way' for the partial Test Ban Treaty in 1963, and he has been a consultant to the Arms Control and Disarmament Association. In 1968 he was a member of the international working party convened by the Stockholm International Peace Research Institute which reopened the question of monitoring underground weapons tests. Since (arter has frequently promised to see a comprehensive test ban agreement with the Sovict Union, Press's experience in such matters is said to have been a strong point in his favour.

Other relevant Washington experi- ence includes a stint on the President's Science Advisory (ommittee (PSAC) from 1961 to 1964. and membership of the National Science Foundation, from 1970) to 1976. He is also (hairman of the National Academy of Sciences' ('ommittee on Scholarly (ommunication with the People's Republic of China, and has travelled extensively in China in recent years.

Even though Press's administrative burden has grown heavier every year, he has continued to make major and distinguished contributions to geophysics. His early work was concerned with seismic wave propagation in the earth's crust and upper mantle. and this eventually resulted in a book Elastic Waves in Lavered Media in collaboration with $M$. Ewing and $W$. Jardetzky. The book had a great influence on the emerging science of seismology. In the 1960s his interests turned to lunar seismology and he was a member of the Apollo team that discovered moonquakes. In the same period he was also encouraging early. US research in earthquake prediction as Chairman of the Karthquake Prediction Panel of the Office of Science and Technology. In the late 1960s he started to work on the problem of inversion of earth data by Monte Carlo methods, and more recently his research has included study of the excitation of the Chandler Wobble by earthquakes. In 1974 he published. with R. Siever, a major geology/ geophysics text Earth.

Colin Norman posals, moreover, are only a foretaste of a comprehensive energy policy which Carter has promised to anveil in midApril.

The budget revisions suggest that the besieged liquid motal fast breeder reactor (I.MFBR) programme is in deep trouble. Carter has recommended that nearly $\$ 200$ million should be taken out of Ford's budget request for the L.MFBR effort next year, a reduction which would still leave $\$ 6.56$ million in the programme, but which would cut spending to bclow this year's level. A statement published last week by the Energy Research and Development Administration (ERDA), which is said to have been Urafted by Schlesinger, announced that the entire L.MFBR programme will be subjected to an intensive review. to "assess the role of I.MFBRs in the nation's energy future. the timing and pace of the breeder programmes and the timing of any decision on whether the breeder would be a viable energy option".

The implications are made clear later in the statement:

The President's energy priorities, as reflected in the revision of ERDA's (fiscal year) 1978 budget request. stress conservation and mearer-term supply technologies. These priorities suggest that past plans for expansion of the LMFBR program may no longer be viable. Furthermore. serious questions have been raised about the LMFBR technology and the structure of the current LMFBR program. The energy potential of this option must be weighed against the safety questions associated with the LMFBR and the dangers of nuclear proliferation from plutonium reprocessing needed by L.MFIBRs.

In particular, the review will focus on ERDA's plans to build a demonstration fast breceler reactor on the (linch River in Tennessec. a project which represents the next major step in the I.MPBR programme in the United States. Construction of the Clinch River plant was scheduled to begin later this year, but it will now be delayed pending the outcome of the review. Conseguently. (arter has suggested that $\$ 8.5$ million be cut from Ford's request for that project alone. No date has been set for completing the review, but it is unlikely that a final decision will be ready in time for inclusion in the energy policy which (arter will unveil in April.

As for solar energy research and development, again. long-term efforts ar: being cut hack to allow more funds to be channelled into programmes likely to produce more immediate results. Aceordingly. Carter has scaled down Ford's budget proposal for construction of a pilot-scale solar thermal gencrating plant, and recommended that the savings be used chiefly to underwrite the costs of producing and testing some 1,300 solar heaters.

The pilot plant project which (arter wants to cut was only given a g()-ahead by the Ford Administration on 7 January. It would entail construction 
of a $10 \mathrm{MW}$ generating plant in the Mojave Desert in California; the plant would essentially consist of a bank of mirrors concentrating the sun's rays onto a steam generator atop a tower. The project, the costs of which would be shared with electric utilities and government bodies in California, was scheduled for completion in 1980 or 1981. Ford had requested $\$ 65$ million for the project next year, but Carter has recommended that the budget be reduced to $\$ 10$ million. The original plan was to follow the California plant with another pilot plant a couple of years later, leading eventually to a commercial-scale plant in the late 1990s. No decision has yet been made on how far the project will be stretched out under Carter's energy policies.

Carter's proposal that more funds be pumped into the production and testing of solar heaters represents a marked change from the policies of the Nixon and Ford Administrations. In 1974. Congress passed a bill to provide federal support for up to 5.000 solar heaters to be installed in public and private buildings and tested over a fiveyear period. The idea was to stimulate the growth of a solar heating industry, but the Ford Administration was opposed to the principle that the federal government should be so directly involved in the market-place. and the legislation consequently was implemented in a relatively half-hearted manner. Carter clearly shares Congress's view that federal support is needed to commercialise new energy technologies.

Similar views show up in Carter's proposals for energy conservation. He has doubled Ford's budget request for research and development on energy- saving systems, recommending that a total of $\$ 318$ million be spent next year. Much of the proposed increase would be devoted to programmes designed to increase the efficiency with which energy is used in industry, buildings and transport, but $\$ 40$ million would also be spent on a programme to provide federal subsidies for the production and testing of electrically powered vehicles. Again, that is an effort which Ford had argued should be the responsibility of private industry rather than of the federal government.

As for the fusion programme, Carter has recommended that $\$ 60$ million be docked from Ford's request for research on magnetic confinement, leaving $\$ 311$ million in the programme. $\mathrm{He}$ also suggested that Ford's request for laser fusion studies be reduced from $\$ 142$ to $\$ 122$ million. Again, the pattern is to decrease support for long-term programmes, but to allow nearer-term efforts to proceed. Thus, the Tokamak Fusion Test Reactor (TFTR), a major facility being built at Princeton University, will be allowed to go ahead, but the completion date would slip by about 6 months, to mid1981. Similarly, a large magnetic mirror machine planned for the L.awrence Livermore I aboratory would suffer a $\$ 10$ million cut, but it would also be allowed to proceed with only a minor slip in schedule.

As far as the addition to NASA's budget is concerned. the Carter Administration has unexpectedly recommended that $\$ 15$ million be spent next year on studies of potential missions to Mars as a follow-up to the successful Viking project: Ford had recommended only $\$ 5$ million for such efforts. Several candidate missions are under consideration, ranging from

\section{Sorry, for copyright reasons some images on this page may not be available online}

\section{Energy man: James Schlesinger}

refurbishing the back-up Viking spacecraft, which was held in reserve in case the original Viking mission failed, and launching it in 1984 , to construction of a new spacecraft to return samples of Martian soil to Earth. The more ambitious missions would probably not be launched until 1988. In any case, planetary scientists are encouraged by Carter's modest budget addition, seeing it as an expression of Presidential interest in the space programme.

The only other budgetary change of note is the fact that Carter has added only $\$ 5$ million to the budget of the National Institutes of Health. Ford's budget request for NIH was relatively parsimonious, providing an increase of only $\$ 40$ million, which is insufficient to keep pace with inflation. Congress traditionally adds substantial increases for NIH. however. and the Carter Administration will probably not object if Congress carries on the tradition this year.

\section{SEVESO}

\section{Dioxin damage}

Alastair Hay reports on recent developments in Seveso and a possible link connecting dioxin with birth defects.

OHIICial confirmation has now come that at least two of the women who were exposed to tetrachlorodibenzo- $p$ dioxin (dioxin) at Séveso last year have given birth to children with malformations. But the director of health for the Lombardy region. Dr Vittoria Rivolta, is quoted as saying that it is "not yet possible to link the deformations with dioxin contamination". The dioxin was present in the discharge from a trichlorophenol reactor which overheated at the ICMESA chemical plant on July 10
The first abnormality to be observed was a slight intestinal obstruction in an infant born on 10 January. The mother had apparently eaten garden produce which was heavily contaminated with dioxin. The second case-a "small genital deformation"-was reported on 7 February. But the mother was resident in an area not officially considered to be contaminated by the chemical.

According to Dr Rivolta both infants underwent successful surgery shortly after birth. He added that, in view of the known teratogenic properties of dioxin, the Lombardy regional health department was keeping "a record of all children who are born with deformations from mothers who were in the Séveso area at the time of the explosion".

The developing human embryo is particularly susceptible to teratogenic agents during the period of organogenesis when tissue and organ differentiation occur. In Man this period generally occurs between gestation day's 18-55. The children born on 10 January and 7 February would therefore have been at a stage of foetal development beyond organogenesis. For that reason they might be considered to have been less susceptible to the teratogenic properties of dioxin. However, as one mammalian development scientist put it. "We don't know the teratogenic mechanism of dioxin and we have no idea at which stage of its development a foetus ceases to be at risk to this chemical".

School children in Séveso and its 